\title{
RELATIONSHIP BETWEEN FAMILY SUPPORT WITH ANXIETY LEVEL IN APPENDICTOMY PREOPERATIVE PATIENTS AT PROF .Dr.SOEKANDAR HOSPITALS MOJOSARI MOJOKERTO DISTRIC
}

\author{
Binarti Dwi W \\ AKPER BINA SEHAT PPNI MOJOKERTO
}

\section{ABSTRACT}

Family support are attitude, action and acceptance family towards patients who get illness. The. The anxiousness is part of human's life that signed by fearfullness or deeply nervousness and having a continously. This research purposes to determine the relationship of family support with anxiety levels in appendictomy preoperative patients at Prof. Dr. Soekandar hospitals Mojokerto. This research is a correlational research with cross sectional approach. The population was all apendictomy preoperative patients. The sampling method was consecutive sampling. The analysis of the relationship of family support and the level of anxiety apply Spearman Rho correlation test showed a significant relationship with $p=0.004(<\alpha 0.05)$. The result showed that family support in medium category was 2 people (13\%), the family support in good category was 12 people (80\%), the family support in excellent category was 1 (7\%), while the number and percentage of respondents who experienced in mild anxiety as much as 4 people (27\%), moderate anxiety as much as 9 people (60\%), and severe anxiety as much as 2 people (13\%). There is no respondents in analysis who have family support in less category, and There is no respondents in analysis who have not experienced a panic and anxiety. The level of anxiety was influenced by family support, pain, ignorance, disanlement, death and anesthesia. However, the factors that affect the level of anxiety that is family support. The anxiousness would be lower if you have a good family support.

Keywords: Family Support, Anxiety Level, appendictompreoperative patient.

\section{Pendahuluan}

Apendeksitis merupakan suatu peradangan apendiks yang mengenai semua lapisan dinding organ tersebut (price.1995). Pembedahan diindikasikan bila diagnosis apendiksitis telah ditegakkan. Apendiktomi (pembedahan untuk mengangkat apendiks) dilakukan segera mungkin untuk mengurangi perforasi (Smeltzer.2002). pada setiap operasi baik mayor ataupun minor pasti akan terjadi ansietas atau kecemasan pada pasien tersebut, begitupun pada pasien yang akan melakukan apendiktomi. Kecemasan praoperatif kemungkinan merupakan suatu respons antisipasi terhadap suatu pengalaman yang dapat dianggap pasien sebagai suatu ancaman terhadap perannya dalam hidup, atau bahkan kehidupannya itu sendiri (Smeltzer.2002). Untuk mengatasi kecemasan dibutuhkan dukungan keluarga. Dukungan keluarga adalah sikap, tindakan dan penerimaan keluarga terhadap penderita yang sakit. Dukungan keluarga tersebut dapat menekan munculnya suatu stressor karena informasi yang diberikan dapat menyumbangkan aksi sugesti yang khusus pada individu. (Akhmadi 2009). Berdasarkan kenyataan dilapangan pasien pre operasi mengalami ansietas / kecemasan akibat kurangnya informasi dan ketakutan akan operasi yang akan dilakukan. Untuk meminimalkan kecemasan, keluarga pasien biasanya memberikan dukungan kepada pasien. Dukungan tersebut biasanya berupa motivasi , mengantar pasien sampai ruang operasi dan bahkan tidak jarang keluarga yang menunggu pasien didepan ruang operasi sampai operasi selesai.

Pada setiap operasi baik mayor ataupun minor pasti akan terjadi ansietas atau kecemasan pada pasien tersebut, begitupun pada pasien yang akan melakukan apendiktomi. Kecemasan praoperatif kemungkinan merupakan suatu respons antisipasi terhadap suatu pengalaman yang dapat dianggap pasien sebagai suatu ancaman terhadap perannya dalam hidup, atau bahkan kehidupannya itu sendiri (Smeltzer.2002). 
Untuk mengatasi kecemasan dibutuhkan dukungan keluarga. Dukungan keluarga adalah sikap, tindakan dan penerimaan keluarga terhadap penderita yang sakit. Dukungan keluarga tersebut dapat menekan munculnya suatu stressor karena informasi yang diberikan dapat menyumbangkan aksi sugesti yang khusus pada individu. (Akhmadi 2009).

Friedmen 1998 ( dalam ainun 2007 ) menyatakan bahwa dukungan keluarga dapat menimbulkan efek penyangga yaitu dukungan keluarga menahan efek-efek negatif dari stress terhadap kesehatan dan efek utama yaitu dukungan keluarga yang secara langsung mempengaruhi pe- ningkatan kesehatan. Dukungan yang baik juga akan meningkatkan harga diri, kemampuan kontrol diri dan kemampuan informasional keluarga pasien preoperasi appendictomy.Sehingga dengan peningkat

-an kemampuan tersebut diharapkan akan meningkatkan kemampuan koping pasien pre operasi appendictomy dalam menghadapi berbagai stressor yang dihadapinya saat akan menjalani appendictomy. Dengan kemampuan koping tersebut maka tingkat kecemasan yang dialami pasien pre operasi appendectomy dapat diminimalisir.

Menurut (Smeltzer.2002) kira-kira $7 \%$ dari populasi akan mengalami apendiksitis dalam waktu yang bersamaan dalam hidup mereka. Apendiksitis paling sering terjadi antara usia 10 sampai 30 tahun (Smeltzer.2002). berdasarkan studi pendahuluan yang dilakukan di RSUD Prof Dr. Soekandar mojokerto, penderita apendiksitis yang rawat inap dan yang dilakukan apendektomi pada bulan januari sampai oktober tahun 2014 sebanyak 67 orang. Sementara pada tanggal 4 dan 11 Desember terdapat 6 pasien yang akan melakukan operasi apendiktomi tetapi yang mengalami kecemasan hanya 5 orang, sementara yang 1 orang belum tidak bisa dikaji tingkat kecemasannya karena masih berumur 3 tahun.

Menurut ramaiah dalam (safariah dan nofrans.2012) ada 6 cara dalam mengatasi kecemasan. Yaitu pengendalian diri, dukungan (dukungan keluarga), tindakan fisik, tidur, mendengarkan musik, dan konsumsi makanan.( safariah dan nofrans.2012). Dari keenam cara tersebut, peneliti ingin meneliti mengenai hubungan dukungan keluarga dengan tingkat kecemasan pada pasien pre operasi apendiktomi.

\section{Metode}

Jenis penelitian yang digunakan yaitu analitik korelasional dengan menggunakan metode pendekatan cross sectional. Populasi dari penelitian ini adalah Semua pasien apendiktomi di RSUD prof. Dr soekandar kab. mojokerto pada bulan Bulan januari juni tahun 2015. pengambilan sampel dilakukan dengan consecutive sampling sehingga didapatkan jumlah sampel yang memenuhi kriteria inklusi dan eksklusi sebanyak 15 responden.

Instrumen yang digunakan dalam penelitian adalah kuesioner yang berisi pertanyataan dan pertanyaan seputar dukungan keluarga dan tingkat kecemasan. Untuk mengukur tingkat kecemasan peneliti menggunakan kuisioner dengan jumlah 14 pertanyaan sedangkan untuk mengukur dukungan keluarga peneliti menggunakan peryataan sebanyak 12 peryataan.Analisa data dengan uji Spearman Rho

\section{Hasil}

Berdasarkan hasil penelitian tentang distribusi responden :

Tabel 1 Distribusi responden berdasarkan usia pada pasien pre operasi apendiktomi di RSUD Prof. Dr. Soekandar Mojosari Kabupaten Mojokerto tanggal 14 Januari s/d 13 April 2015

\begin{tabular}{llll}
\hline No. & Usia & Frekuensi & Prosentase \\
\hline $\mathbf{1}$ & $<20$ & 0 & $0 \%$ \\
$\mathbf{2}$ & $20-30$ & 9 & $60 \%$ \\
$\mathbf{3}$ & $31-40$ & 6 & $40 \%$ \\
jumlah & 15 & $100 \%$ \\
\hline
\end{tabular}

Dari tabel di atas dapat dilihat karakteristik responden berdasarkan sebagian besar usia karakteristik responden usia 20-30 tahun sebanyak 9 orang $(60 \%)$, 
Tabel 2 Distribusi responden berdasarkan jenjang pendidikan pada pasien pre operasi apendiktomi di RSUD Prof. Dr. Soekandar Mojosari Kabupaten Mojokerto tanggal 14 Januari s/d 13 April 2015.

\begin{tabular}{llll}
\hline No & Pendidikan & frekuensi & prosentase \\
\hline $\mathbf{1}$ & SD & 3 & $20 \%$ \\
$\mathbf{2}$ & SLTP & 5 & $33 \%$ \\
$\mathbf{3}$ & SLTA & 7 & $47 \%$ \\
Jumlah & 15 & $100 \%$ \\
\hline
\end{tabular}

Dari tabel di atas dapat dilihat karakteristik responden berdasarkan jenjang pendidikan SD sebanyak 3 orang (20\%), karakteristik responden berdasarkan jenjang pendidikan SLTP sebanyak 5 orang (33\%) dan karakteristik responden berdasarkan jenjang pendidikan SLTA sebanyak 7 orang (47\%).

Tabel 3 Distribusi responden berdasarkan pekerjaan pada pasien pre operasi apendiktomi di RSUD Prof. Dr. Soekandar Mojosari Kabupaten Mojokerto tanggal 14 Januari s/d 13 April 2015

\begin{tabular}{llll}
\hline No. & Pekerjaan & f & \% \\
\hline $\mathbf{1}$ & Buruh & 3 & $20 \%$ \\
$\mathbf{2}$ & Swasta & 6 & $40 \%$ \\
$\mathbf{3}$ & PNS & 2 & $13 \%$ \\
$\mathbf{4}$ & IRT & 4 & $27 \%$ \\
& Jumlah & 15 & $100 \%$ \\
\hline
\end{tabular}

Dari tabel di atas dapat dilihat karakteristik responden berdasarkan pekerjaan sebagai buruh sebanyak 3 orang (20\%), sebagai pekerja swasta sebanyak 6 orang (40\%), sebagai PNS sebanyak 2 orang (13\%) dan sebagai ibu rumah tangga sebanyak 4 orang $(27 \%)$.

Tabel 4 Distribusi data berdasarkan tingkat kecemasanpada pasien pre operasi apendiktomi di RSUD Prof. Dr. Soekandar Mojosari Kabupaten Mojokertotanggal 14 Januari s/d 13 April 2015.

\begin{tabular}{ll|ll}
\hline No & $\begin{array}{l}\text { Tingkat } \\
\text { Kecemasan }\end{array}$ & f & \% \\
\hline $\mathbf{1}$ & Ringan & 4 & $27 \%$ \\
$\mathbf{2}$ & Sedang & 9 & $60 \%$ \\
$\mathbf{3}$ & Berat & 2 & $13 \%$ \\
$\mathbf{4}$ & Panik & 0 & $0 \%$ \\
\hline & Jumlah & 15 & $100 \%$ \\
\hline
\end{tabular}

Dari tabel diatas didapatkan hasil bahwa responden yang mengalami cemas tingkat ringan sebanyak 4 orang (27\%), cemas sedang sebanyak 9 orang $(60 \%)$, cemas berat sebanyak 2 orang $(13 \%)$, dan tidak ada responden yang mengalami panik serta tidak ada responden yang tidak mengalami cemas pre operasi apendiktomi.

Tabel 5 Distribusi data berdasarkan dukungan keluargapada pasien pre operasi apendiktomi di RSUD Prof. Dr. Soekandar Mojosari Kabupaten Mojokerto tanggal 14 Januari s/d 13 April 2015.

\begin{tabular}{llll}
\hline No & $\begin{array}{l}\text { Dukungan } \\
\text { Keluarga }\end{array}$ & f & \% \\
\hline $\mathbf{1}$ & Kurang & 0 & $0 \%$ \\
$\mathbf{2}$ & Cukup & 2 & $13 \%$ \\
$\mathbf{4}$ & Baik & 12 & $80 \%$ \\
$\mathbf{3}$ & Sangat Baik & 1 & $7 \%$ \\
\hline Jumlah & 15 & $100 \%$ \\
\hline
\end{tabular}

Dari tabel diatas dapat diidentifikasi bahwa tidak ada reponden penelitian yang memiliki tingkat dukungan keluarga kurang, terdapat 2 responden memiliki dukungan keluarga tingkat cukup/sedang atau sekitar 13\%, terdapat 12 responden memiliki dukungan keluarga tingkat baik atau sekitar $80 \%$ dan responden yang memiliki dukungan keluarga sangat baik sebanyak 1 orang atau sekitar $7 \%$.

Tabel 6 Distribusi data berdasarkan hubungan dukungan keluarga dengan tingkat kecemasan pada pasien pre operasi apendiktomi di RSUD Prof. Dr. Soekandar Mojosari Kabupaten Mojokerto tanggal 14 Januari s/d 13 April 2015 .

\begin{tabular}{|c|c|c|c|c|c|c|c|c|c|c|c|}
\hline & \multicolumn{10}{|c|}{ Dukunģan Keluarga } \\
\hline & & \multicolumn{2}{|c|}{ kurang } & \multicolumn{2}{|c|}{ cukup } & \multicolumn{2}{|c|}{ baik } & \multicolumn{2}{|c|}{ sangat baik } & \multicolumn{2}{|c|}{ jumlak } \\
\hline & & $\mathrm{f}$ & $\%$ & f & $\%$ & $\mathrm{f}$ & $\%$ & $\mathrm{f}$ & $\%$ & f & $\%$ \\
\hline \multirow{4}{*}{\begin{tabular}{|l} 
Tingka: \\
Kecemasn
\end{tabular}} & ringan & 0 & 0 & 0 & 0 & 3 & 75 & 1 & 25 & 4 & 100 \\
\hline & sedang & 0 & 0 & 0 & 0 & 9 & 100 & 0 & 0 & 9 & 100 \\
\hline & berat & 0 & 0 & 2 & 100 & 0 & 0 & 0 & 0 & 2 & 100 \\
\hline & pank & 0 & 0 & 0 & 0 & 0 & 0 & 0 & 0 & 0 & 0 \\
\hline Jumlah & & 0 & 0 & 2 & & 12 & & 1 & & 15 & 100 \\
\hline
\end{tabular}

Dari tabel diatas didapatkan 12 responden yang memiliki dukungan keluarga kategori baik namun 8 orang diantaranya mengalami kecemasan tingkat sedang dan 4 orang mengalami kecemasan tingkat sedang 
begitupun responden yang memiliki dukungan keluarga kategori sangat baik sebanyak 1 orang dan mengalami kecemasan tingkat ringan. Sedangkan responden yang memiliki dukungan keluarga cukup ada 2 orang dan keduanya mengalami kecemasan tingkat berat.

Dari hasil uji statistik korelasi Spearman, didapatkan hasil Pvalue $=0,002$ lebih kecil dari $\alpha=0,05$. Hal ini berarti bahwa terdapat hubungan signifikan antara dukungan keluarga dengan tingkat kecemasan pada pasien pre operasi apendiktomi di RSUD Prof. Dr. Soekandar Mojosari Kabupaten Mojokerto .

\section{Pembahasan}

1.Dukungan keluarga pada pasien pre operasi appendiktomi di RSUD Prof. Dr. Soekandar Mojosari Kabupaten Mojokerto

Berdasarkan hasil penelitian yang telah dilakukan selama 6 bulan dari tanggal 14 Januari s/d 13 April 2015. pada 15 responden, dapat diidentifikasi bahwa tidak ada reponden penelitian yang memiliki tingkat dukungan keluarga kurang, terdapat 2 responden memiliki dukungan keluarga tingkat cukup atau sekitar $13 \%$, terdapat 12 responden memiliki dukungan keluarga tingkat baik atau sekitar $80 \%$ dan responden yang memiliki dukungan keluarga sangat baik sebanyak 1 orang atau sekitar $7 \%$.

Dukungan keluarga merupakan informasi verbal atau non verbal, saran, bantuan yang nyata atau tingkah laku yang diberikan oleh orang-orang yang akrab dengan subjek di dalam lingkungan sosialnya atau yang berupa kehadiran dan hal-hal yang dapat memberikan keuntungan emosional atau berpengaruh pada tingkah laku penerimanya.(Azizah, 2011). Dukungan keluarga dipengaruhi oleh beberapa faktor, yaitu; keiintiman, harga diri, keterampilan sosial, umur, pendidikan, spiritual dan status sosial ekonomi (Rahayu 2009)

Usia akan mempengaruhi tingkat pemahaman responden terhadap suatu dukungan yang diberikan oleh anggota keluarganya. Sementara tingkat pendidikan akan membentuk pola pikir dan pemahaman yang berbeda pada setiap orang. Semakin tinggi tingkat pendidikan seseorang biasanya akan memberikan pola pikir dan pemahaman yang lebih baik terhadap suatu hal. Sedangkan Pekerjaan yang dimiliki akan sangat berpengaruh terhadap tingkat pendapatan keluarga. Keluarga dengat tingkat pendapatan yang tinggi secara tidak langsung akan membuat keluarga tersebut masuk kedalam keluarga dengan status soial atas, sebaliknya jika pendapatanya rendah keluarga tersebuat akan masuk dalam dalam kelas sosial bawah. Kelas sosial akan berpengaruh banyak terhadap keterlibatan keluarga dalam memberikan dukungan keluarga terhadap salah satu anggota keluarganya yang sakit.(Smeltzer 2002).

2.Tingkat kecemasan pada pasien pre operasi appendiktomi di RSUD Prof. Dr. Soekandar Mojosari Kabupaten Mojokerto

Berdasarkan hasil penelitian yang telah dilakukan selama 6 bulan dari tanggal 14 Januari s/d 13 April 2015 pada 15 responden, didapatkan hasil bahwa responden yang mengalami cemas tingkat ringan sebanyak 4 orang $(27 \%)$, cemas sedang sebanyak 9 orang $(60 \%)$, cemas berat sebanyak 2 orang (13\%), dan tidak ada responden yang mengalami panik serta tidak ada responden yang tidak mengalami cemas pre operasi apendiktomi.

Kecemasaan adalah keadaan dimana seseorang mengalami perasaan gelisah atau cemas dan aktifitas sistem syaraf otonom dalam merespon terhadap ancaman yang tidak jelas dan tidak spesifik (Carpenito, 2000). Sedangkan menurut asmadi (2008), Ansietas atau kecemasan merupakan gejolak emosi seseorang yang berhubungan dengan sesuatu diluar dirinya dan mekanisme diri yang digunakan dalam mengatasi pemasalahan. (Asmadi.2008).

Segala bentuk prosedur pembedahan selalu didahului dengan suatu reaksi emosional tertentu oleh pasien, apakah reaksi itu jelas atau tersembunyi, normal atau abnormal. Sebagai contoh, kecemasan pre operatif kemungkinan merupakan suatu respon antisipasi terhadap suatu pengalaman yang dapat dianggap pasien sebagai suatu ancaman terhadap perannya dalam hidup, integritas tubuh, atau bahkan kehidupannya itu sendiri (Smeltzer 2002).

Menjelang operasi pasti semua orang akan merasakan kecemasan. Kecemasan itu muncul seiring dengan pandangan dan pemahaman seseorang terhadap operasi itu sendiri. Kebanyakan sesorang akan merasa 
takut menjelang operasi. Perasaan takut itu muncul seiring dengan adanya pandangan seseorang akan adanya suatu ancaman seperti ; kecacatan, nyeri atau rasa sakit saat operasi, kegagalan operasi, kematian dll. Pandangan dan pemahaman seseorang dipengruhi oleh usia, pendidikan dan pekerjaan (status soial) seseorang.

Dari data diatas dapat dilihat bahwa seluruh responden mengalami kecemasan menjelang operasi apendiktomi yang akan dilakukan dan sebagian besar responden mengalami kecemasan pada tingkat sedang. Menjelang operasi pasti semua orang akan merasakan kecemasan. Kecemasan itu muncul seiring dengan pandangan dan pemahaman seseorang terhadap operasi itu sendiri. Kebanyakan sesorang akan merasa takut menjelang operasi. Perasaan takut itu muncul seiring dengan adanya pandangan seseorang akan adanya suatu ancaman seperti ; kecacatan, nyeri atau rasa sakit saat operasi, kegagalan operasi, kematian dll. Pandangan dan pemahaman seseorang dipengruhi oleh usia, pendidikan dan pekerjaan (status soial) seseorang.

3.Hubungan dukungan keluarga dengan tingkat kecemasan pada pasien pre operasi appendiktomi di RSUD Prof. Dr. Soekandar Mojosari Kabupaten Mojokerto Berdasarkan distribusi silang dukungan keluarga dengan tingkat kecemasan pada pasien pre operasi apendiktomi, terdapat 12 responden yang memiliki dukungan keluarga kategori baik namun 9 orang diantaranya mengalami kecemasan tingkat sedang dan 3 orang mengalami kecemasan tingkat ringan begitupun responden yang memiliki dukungan keluarga kategori sangat baik sebanyak 1 orang dan mengalami kecemasan tingkat ringan. Sedangkan responden yang memiliki dukungan keluarga cukup ada 2 orang dan keduanya mengalami kecemasan tingkat berat.

Dukungan keluarga dipengaruhi oleh beberapa faktor, yaitu; keiintiman, harga diri, keterampilan sosial, umur, pendidikan, spiritual dan status sosial ekonomi (Rahayu 2009), Dukungan keluarga yang positif berhubungan dengan kurangnya kecemasan. kecemasan akan rendah apabila individu memiliki dukungan sosial yang baik. menurut Saharon. (2000), ada beberapa faktor yang mempengaruhi kecemasan pada pasien pre operasi antara lain :

a. Nyeri dan ketidaknyamanan (pain and discomfort)

b. Ketidaktahuan (unknow)

c. Kerusakan atau kecacatan (mutilation)

d. Kematian (death)

e. Anestesi (anesthesia)

Dari hasil uji statistik korelasi Spearman, didapatkan hasil Pvalue $=0,002$ lebih kecil dari $\alpha=0,05$. Hal ini berarti bahwa terdapat hubungan signifikan antara dukungan keluarga dengan tingkat kecemasan pada pasien pre operasi apendiktomi di RSUD Prof. Dr. Soekandar Mojosari Kabupaten Mojokerto.

\section{Kesimpulan}

Dari hasil penelitian yang telah dilakukan selama 6 bulan dari tanggal 14 Januari s/d 13 April 2015 di RSUD Prof. Dr. SOEKANDAR MOJOKERTO, dapat ditarik kesimpulan bahwa dari 15 responden kebanyakan mendapatkan dukungan keluarga tingkat baik yaitu sebnyak 12 responden atau sekitar $80 \%$. Sedangkan untuk tingkat kecemasan kebanyakan responden mengalami kecemasan tingkat sedang, yaitu sebanyak 9 orang atau sekitar $(60 \%)$. Dari hasil uji statistik korelasi Spearman, didapatkan hasil Pvalue $=0,002$ lebih kecil dari $\alpha=0,05$. Hal ini berarti bahwa terdapat hubungan signifikan antara dukungan keluarga dengan tingkat kecemasan pada pasien pre operasi apendiktomi di RSUD Prof. Dr. SOEKANDAR MOJOKERTO .

\section{Saran}

Bagi pasien pre operasi apendisitis

Bagi pasien yang mengalami kecemasan pre operasi apendisitis diharapkan berusaha mengungkapkan, dan berbagi kepada keluarga tentang kecemasan yang dialaminya agar tercipta suasana emosional dan dukungan dari keluarga sehingga kecemasan yang dialami akan berkurang.

Bagi keluarga pasien pre operasi apendiktomi Keluarga diharapkan memberikan dukungan sosial semaksimal mungkin kepada pasien berupa dukungan instrumental, dukungan informasional, dukungan penilaian, dan dukungan emosional. 
Bagi tenaga perawat

Diharapkan memberikan dorongan untuk pengungkapan perasaan klien, harus mendengarkan dan harus memahami ungkapan klien, serta memberikan informasi mengenai prosedur operasi apendiktomi yang membantu menyingkirkan rasa cemas pada pasien pre operasi apendiktomi.

Bagi RSUD Prof. Dr. SOEKANDAR MOJOKERTO

Diharapkan meningkatkan mutu pelayanan di ruang rawat inap bedah dengan cara melibatkan keluarga dalam memberikan dukungan pada pasien yang akan menjalani operasi apendiktomi.

Bagi peneliti selanjutnya

Diharapkan bagi peneliti selanjutnya untuk meneliti hubungan dukungan keluarga dengan tingkat kecemasan pada pasien pre operasi apendisitis secara mendetail dan menggunakan sampel yang lebih banyak.

Bagi institusi pendidikan

Diharapkan untuk membekali mahasiswa dengan wawasan ilmu kesehatan yang luas dan memberikan pemahaman mendalam kepada mahasiswa dalam penyusunan karya tulis ilmiah.

DAFTAR PUSTAKA

Ainun. 2012.Hubungan Antara Dukungan Keluarga Dengan Tingkat Kecemasan Pada Pasien Pre Operasi Appendictomy Di Ruang Flamboyan Rsud Tarakan Pemerintah Provinsi Kalimantan Timur.(internet).Available from ( http://www.old.fk.ub.ac.) (accessed 29 november 2013)

Akhmadi.2009.dukungan keluarga. (Internet) 9 Agustus 2009. Available from: (http://www.rajawana.com) (Accessed 21 Oktober 2013)

Alimul H. Aziz (2007), Riset Keperawatan dan Teknik Penulisan Ilmiah, Edisi kedua. Jakarta ; Salemba Medika

Asmadi. 2008. Konsep dan aplikasi kebutuhan dasar klien. Jakarta : salemba medika

Azizah, L.M. 2011. Keperawatan Lanjut Usia. Yogyakarta: Graha Ilmu
Azwar, S. 2008. Sikap Manusia Teori dan Pengukurannya. Edisi 2. Cetakan XII. Jakarta: Pustaka Pelajar

Budiarto. 2002. Biostatistik Untuk Kedokteran dan Kesehatan Masyarakat. Jakarta: EGC

Friedman, M. 1998. Keperawatan Keluarga: Teori dan Praktik. Jakarta: EGC.

Hariyono, Rudy .2000.Mengatasi Rasa Cemas. Gresik: Putra Pelajar

Weistein, Sharon M. (2000). Buku Saku Terapi Intravena Edisi 2. Jakarta: EGC.

Notoatmodjo, S. 2010. Metode Penelitian Kesehatan. Jakarta: Rineka Cipta

Nursalam. 2008. Konsep dan Penerapan Metodologi Penelitian Ilmu Keperawatan. Jakarta: Salemba Medika

Price, sylvia anderson.1995. Fisiologi proses-proses penyakit. Jakarta : EGC

Rahayu, S.H. 2009. Hubungan antara Pengetahuan Keluarga dengan Dukungan Keluarga dalam Perawatan DM di Desa Pamongan Kecamatan Guntur Kabupaten Demak. (Internet). 23 November 2009. Available from: (http://www.digilib.unimus.ac.id) (Accessed 17 Oktober 2013)

Smeltzer, Suzanne C.2002.keperawatan medikal bedah. Jakarta : EGC

Triantoro Safariah Dan Nofrans Eka Saputra.2012.manajemen emosi.jakarta: PT bumi aksara 